\title{
Southamptorston
}

University of Southampton Research Repository ePrints Soton Copyright Notice

Copyright and Moral Rights for this chapter are retained by the copyright owners. A copy can be downloaded for personal non-commercial research or study, without prior permission or charge. This chapter cannot be reproduced or quoted extensively from without first obtaining permission in writing from the copyright holder/s. the content must not be changed in any way or sold commercially in any format or medium without the formal permission of the rights holder.

When referring to this work state full bibliographic details including the author of the chapter, title of the chapter, editor of the book, title of the book, publisher, place of publication, year of publication, page numbers of the chapter

\begin{tabular}{|l|l|}
\hline Author of the chapter & Jeanice Brooks \\
\hline Title of the chapter & $\begin{array}{l}\text { Chivalric Romance, Courtly Love and Courtly Song: } \\
\text { Female Vocality and Feminine desire in the Word of } \\
\text { Amadis de Gaule }\end{array}$ \\
\hline Editor/s & Thomasin Lamay \\
\hline Title of the book & $\begin{array}{l}\text { Musical Voices of Early Modern Women: Many- Headed } \\
\text { melodies }\end{array}$ \\
\hline ISBN & $13: 978-0-7546-3742-4$ \\
\hline Publisher & Ashgate Publishing Limited \\
\hline Place of publication & Aldersholt, England \\
\hline Year of publication & 2005 \\
\hline Chapter/Page numbers & Chapter 3 63-93pp \\
\hline
\end{tabular}




\title{
Chapter 3
}

\section{Chivalric Romance, Courtly Love and Courtly Song: Female Vocality and Feminine Desire in the World of Amadis de Gaule}

\author{
Jeanice Brooks
}

First published in 1548 , these verses on reading an enthralling novel will strike a chord with any modern reader who has been mesmerized by a page-turner:

Et si quelqu'un à le lire s'espreuve,

Pour la douceur, et soulas qu'il y treuve,

Il en perdra le boire et le menger,

Il laissera à son profit songer,

Puys quand aura quelque peu de sejour,

$Y$ passera et la nuyt et le jour,

Ne delaissant de lire incessament,

Tant que iceluy ait leu entierement.

Et peu apres s'il vient à y penser,

Vouloir aura de le recommencer... '

[And when someone sets himself to read it,

The sweetness and pleasure he finds in it

Will cause him to forget to eat and drink,

He will leave off thinking about his business,

Then when he has a little leisure,

He will spend night and day over it,

Never stopping to read incessantly

Until he has read it completely,

And soon after, if he happens to think upon it,

${ }^{*}$ My thanks to Matthew Head, Ellen Harris and Marian Rothstein for their advice and comments on an earlier draft of this essay.

${ }^{1}$ Michel Sévin d'Orléans, prefatory poem to Le huitiesme livre d'Amadis de Gaule, trans. Nicolas de Herberay des Essarts (Paris: Groulleau, Longis \& Sertenas, 1548), cited after Hugues Vaganay, Amadis en français. Essai de bibliographie (Florence: Olschki, 1906; reprint, Geneva: Slatkine, 1970), 75. 
He will want to start it all over again...]

Another contemporary describes how he devoured the first five volumes of the same work, each installment whetting his appetite for the next. Discovering that the sixth volume has yet to appear, he finds himself wishing he had not yet read the others so he can have the pleasure of starting the whole cycle again. ${ }^{2}$ Both of these testimonies were printed with editions of the book itself, and might perhaps be dismissed as elements of publishing propaganda. Yet even hostile witnesses were obliged to concede the work's popularity: though he condemns the effects of reading the novel, François de La Noue admits that it was so beloved at the court of Henri II of France that people would have spit in the face of anyone foolish enough to disparage it. ${ }^{3}$

The novel that elicited such reactions was Amadis de Gaule, the sprawling chivalric romance that was the literary sensation of sixteenth-century France. The model for the French redaction was a Spanish romance so successful that François I commanded his courtier Nicolas de Herberay des Essarts to make a French translation. ${ }^{4}$ Herberay des Essarts expanded considerably on his model, freely amplifying and rearranging material to align the novel more closely with French courtly sensibilities. At the same time, he fashioned a supple, lyrical prose style that resonated with contemporary projects of linguistic enrichment. So distinctive and appealing was the style that it became a model for courtly speech and writing, and a new verb - amadiser, meaning to speak in a sweetly ornate fashion - entered the French vocabulary. ${ }^{5}$ After the publication of the first book in 1540, Herberay des Essarts produced seven further volumes before his death in 1552; a series of different writers translated subsequent volumes up to the appearance of book 24 in 1615. Re-editions of the earlier books continued throughout the century, and collections of extracts - the "thresors" of the romance - ensured the wide dissemination of its most admired speeches. ${ }^{6}$

${ }^{2}$ Ibid., 38 .

${ }^{3}$ François de La Noue, Discours politiques et militaires (1581), ed. F.E. Sutcliffe (Geneva: Droz, 1967), 162.

${ }^{4}$ On the background of the French version, see Yves Giraud's introduction to $L e$ premier livre d'Amadis de Gaule, ed. Yves Giraud and Hugues Vaganay (Paris: Société des Textes Français Modernes, 1986), 5-6. Herberay des Essarts's biography is most thoroughly treated in Michel Simonin, "La disgrâce d'Amadis," Studi Francesi 28 (1984): 1-35.

${ }^{5}$ On Herberay des Essarts's style as model, see Véronique Benhaïm, "Les Thresors d'Amadis," in: Les Amadis en France au XVle siècle, ed. Robert Aulotte (Paris: Editions rue d'Ulm, 2000), 164-180 and Mireille Huchon, "Amadis, 'Parfaicte idée de nostre langue françoise'," in: Les Amadis en France, ed. Aulotte, 183-200.

'The first four volumes in French are modeled on Garcì Rodríguez de Montalvo's Spanish romance; later volumes draw on sequels by other Spanish (and later, Italian) writers. Robert Aulotte, ed., Les Amadis en France, 209-211, supplies a list of early editions of volumes 1-14 of the French cycle and matches them to their Spanish originals; see also Hugues Vaganay, "Les éditions in- $8^{\circ}$ de l'Amadis français," Revue hispanique 85 (1929): 153. Vaganay, Amadis en français, and the bibliography of book 1 in Giraud and Vaganay, 
If contemporary testimony can be believed, almost everyone in sixteenth century France who could read, read Amadis de Gaule. But the unmitigated success of the early decades yielded to more mixed reactions in the second half of the century. Though the novel was still widely read, its erotic aspects became a target for moralists, while military writers deplored the improbably fantastic quality of the combat episodes. Its polished language was linked with a courtly love of style for style's sake, regarded with distrust; amadiser acquired pejorative connotations, and was most frequently used to describe a kind of sweet talking used to camouflage lascivious intentions. At the same time, and perhaps as a corollary, Amadis became more closely identified with a female reading public, a readership explicitly targeted by printers and translators. ${ }^{7}$ The luxurious folio format adopted for the volumes by Herberay des Essarts soon gave way to smaller re-editions; the first octavo edition of Book 1, printed in 1548, included a poem by Jean Maugin addressed "aux dames françoises" explaining that the smaller size would allow them to carry their favorite book more easily. ${ }^{8}$ In the same year, Thomas Sébillet advised budding authors that if they wanted to be well received by women readers, they should adopt the style of Amadis, "le langage desquels est reçu en la bouche d'elles, comme plus doux et savoureux." "While Herberay des Essarts had dedicated his adaptations to male royal and military patrons, from 1552 subsequent translators addressed their books to prominent court noblewomen. Though there has been some debate over how to interpret these gestures, it seems

eds., Amadis I, 24-26. Marian Rothstein points out that the commercial success of Amadis was such that its editions take up ten times more space than any other work in Richard Cooper's "Outline Bibliography of Works on Chivalry Published in France Before 1600" (in Chivalry in the Renaissance, ed. Sydney Anglo (Rochester: Boydell, 1990)), cited in Rothstein, Reading in the Renaissance: Amadis de Gaule and the Lessons of Memory (Newark: University of Delaware Press, 1999), 32. On the "thresors," see Benhaïm, "Les Thresors," and Hugues Vaganay, "Les trésors d'Amadis: essai de bibliographie," Revue hispanique 57 (1923): 115-126.

${ }^{7}$ On the readership of Amadis, see Rothstein, Reading in the Renaissance, 114-124. Simonin, "La disgrâce," tracks the novel's declining reputation, though Nicole Cazauran warns against an over-facile equation of fading critical fortunes with a decline in readership Nicole Cazauran, "Amadis de Gaule en 1540: un nouveau 'roman de chevalerie'?," in: Les Amadis, ed. Aulotte, 22n. Benhaïm, "Les Thresors," shows that the extracts preserved in the Thresors extended the exemplary power of Amadis well after the fashion for the novel as a whole had begun to wane.

${ }^{8}$ The poem is edited in Vaganay, Amadis en français, 14. On the format of early editions, see Rothstein, Reading in the Renaissance, 32-34.

9 "The language of which is received in their mouths, as the sweetest and most delicious." Thomas Sébillet, Art poétique français, ed. Félix Gaiffe, revised by Françis Goyet (Paris: Société des Textes Français Modernes, 1988), 61. Note Sébillet's expression, which suggests that female readers find speaking the words pleasurable; this notion will prove significant in my interpretation. 
clear that by the second half of the sixteenth century, the Amadis novels had indeed begun to enjoy a substantial female readership. ${ }^{10}$

These shifts in the romance's reception in the second half of the century coincided with a moment when women were a conspicuous presence in prints of courtly song. In the early 1570 s, the worlds of Amadis and of court song were especially closely enmeshed: both song books and new Amadis translations emanated from a Neoplatonic and Neopetrarchan salon environment inhabited by female patrons, readers and performers. Links in production and reception were matched by correspondences in content, for song texts frequently mirror moments of speech in the romance. Romance thus appears as a potentially powerful tool for interpreting the cultural role of French song at an important juncture in its history, when the popularizing strophic pieces formerly known as voix de ville were cultivated with increasing assiduity at court.

Romance as delineated by romantic fiction and popular song - in both historical and modern contexts - has been a topic of fierce controversy among feminist historians, sociologists and literary critics, variously regarded as opiate aimed at duping women into submission to patriarchy, or opportunity for imaginary escape from the dreary lives that patriarchy may impose. ${ }^{11}$ The debate has underlined the importance of exploring the uses of romance in actual women's lives if we are to understand its undeniable appeal to female audiences both past and present. How precisely to go about such an investigation is less clear, however, and a range of different reader- and audience-centered approaches have been applied to romantic songs and fiction in recent decades. The application of sociological methods to collect data about consumers of romance has proved particularly fruitful for studying contemporary fiction; despite the obvious constraints on the amount of information we can assemble about historical readers, they too have become a newly important focus of study. ${ }^{12}$ The influence of

10 Helen Hackett (Women and Romance Fiction in the English Renaissance (Cambridge: Cambridge University Press, 2000), 4-19) observes that appeals to female readers in novels' prefatory material could function as an advertisement of the racy, emotional aspect of the books to male book buyers, and are as much a function of the feminization of romance as a genre as an indication of an actual female reading public. Elizabeth Spearing, however, on the basis of ownership marks and other evidence, argues for a large female readership for Amadis ("The Representation of Women and Gender in the Amadis Cycle," D.Phil. dissertation, University of York, 1991, 17).

${ }^{11}$ For an excellent overview of the issues, see Susan Ostrov Weisser's introduction to Women and Romance: A Reader (New York: New York University Press, 2001), 1-6.

${ }^{12}$ The most influential study of contemporary readers of romantic fiction has been Janice Radway, Reading the Romance: Women, Patriarchy and Popular Literature (Chapel Hill: University of North Carolina Press, 1984; reprint, with new introduction, 1991). Reader-oriented studies of Renaissance romance include Rothstein, Reading in the Renaissance; see also Helen Hackett, Women and Romance Fiction. For a discussion of some of the challenges inherent in attempts to recover the reactions of historical women readers, see Roberta L. Krueger, Women Readers and the Ideology of Gender in Old French Verse Romance (Cambridge: Cambridge University Press, 1993), 17-32. 
psychoanalytic theory on recent literary criticism has ensured that readers' experience of sexuality and desire has become a central concern in post-Freudian examinations of the relationship of reader and text, though often with unacceptable results for feminist scholars. Classic psychoanalytic accounts assume that desire is an innate human urge that seeks to find expression through romance, an assumption that problematically denies the specificity of readerly activity upon which historical-sociological studies are based and the potential for change to which feminist principles are committed. ${ }^{13}$ My own investigation thus takes as a fundamental premise that romance is one means by which desire is produced. Its constructions are historically and socially contingent: romantic songs and fiction are used by their audiences in culturally specific ways to invent their own versions of desire. ${ }^{14}$ In what follows, I first sketch the outlines of the environment in which romance was cultivated in sixteenth-century France, to show that Amadis de Gaule and the court song repertory were produced for and consumed by the same interpretive community of female readers, singers and listeners. I then consider what these musical and literary romantic narratives meant for this community, and how novels and songs figured in vocal performances of feminine desire in French courtly circles of the late Renaissance.

Amadis de Gaule has much in common with the chivalric romances cultivated in France throughout the middle ages. Its structure is episodic, spawning seemingly endless numbers of characters and subplots. The narrative meanders from adventure to adventure, often leaving characters pining in towers or sailing across oceans while doubling back to rescue others who are in the clutches of malevolent giants or under a sorceress's evil spell. As the title page of the first volume declares, Amadis "relates many adventures of arms and love, had by several knights and ladies" ("traicte de maintes adventures d'Armes et d'Amours, qu'eurent plusieurs Chevaliers et Dames") and, as in earlier romances, a large portion of each book is devoted to descriptions of the prodigious feats of daring knights. ${ }^{15}$

${ }^{13}$ Such principles underlie, for example, Lawrence D. Kritzman, The Rhetoric of Sexuality and the Literature of the French Renaissance (Cambridge: Cambridge University Press, 1991).

${ }^{14}$ This is not to reject a potential role to the unconscious, or to deny the similarities that may exist between different cultures' configurations of desire, but to emphasize that the experience and understanding of desire has varied over time and across divisions of e.g. class, sexuality and gender. See Stevi Jackson, "Love and Romance as Objects of Feminist Knowledge," in: Making Connections: Women's Studies, Women's Movements, Women's Lives, ed. Mary Kennedy, Cathy Lubelska, and Val Walsh (Washington, D.C.: Taylor and Francis, 1993; reprinted in Weisser, ed. Women and Romance), 260-261.

${ }^{15}$ Giraud and Vaganay, eds., Amadis I, 9-10, characterises the structure as archaic, privileging luxuriance over coherence; see also Rothstein, Reading in the Renaissance, 6470, and John J. O'Connor, Amadis de Gaule and its Influence on Elizabethan Literature (New Brunswick, N.J.: Rutgers University Press, 1970), 85-129. 
The Amadis cycle differs from its medieval and Spanish forebears in its much greater emphasis on love episodes, which are strongly imbued with the Neoplatonist and Neopetrarchan ideals that shaped French court culture from the 1540 s onward. Herberay des Essarts's Amadis is not only perfect warrior but perfect lover. His relationship with his adored Oriane illustrates a quest for spiritual perfection through worldly love that would have seemed familiar to readers of Ficino, Castiglione, Leone Ebreo and their French translators and adaptors. These qualities of the French Amadis have a special impact on the female characters of the romance. As women rarely figure in battle scenes except as pretext, the increased attention to love allows them a larger share of the novel's action than in Amadis's predecessors. And the instrumental function of women in Neoplatonic love theory affords their role within these episodes a heightened significance in comparison with their earlier counterparts. ${ }^{16}$

Since the novel so consistently reflects Neoplatonic ideals, it is not surprising that the impetus for a new round of Amadis volumes in the early 1570 s came from the circle around Claude-Catherine de Clermont, comtesse de Retz. Gatherings in her salon nourished a fertile creative environment whose traces have been abundantly preserved in contemporary prints and manuscripts. ${ }^{17}$ The Retz circle is well known to literary scholars for its role in fostering a new wave of Neoplatonist and Neopetrarchan writing in the 1570s, which involved poets of the Pléiade as well as the younger generation of Jamin and Desportes. The salon also played an important part in the history of the French Amadis. Jacques Gohory's 1571 translation of the Trezieme livre is dedicated to Catherine de Clermont, and contains a preface explaining that his work on the book was undertaken at her request. Gohory, a humanist and alchemist with strong occult leanings, had translated volumes 10 and 11 of the series nearly twenty years previously; his return to the novel after such a long lapse supports his contention that the 1571

${ }^{16}$ See Rothstein, Reading in the Renaissance, 52-60 on the Neoplatonic conversion of Amadis; Catherine Mary Hampton, "Chastity: A Literary and Cultural Icon of the French Sixteenth-Century Court" (Ph.D. diss., University of Durham, 1996), 201-215, discusses the novel's illustration of the Neoplatonic icon of chastity.

${ }^{17}$ For biographical information on Catherine de Clermont, see Mme Michel Jullien de Pormmerol [Marie-Henriette de Montéty], Albert de Gondi, Maréchal de Retz (Geneva: Droz, 1953), 195-218, and Christie Ellen St-John, "The Salon vert of the Maréchale de Retz: A Study of a Literary Salon in Sixteenth-Century France" (Ph.D. diss., Vanderbilt University, 1999). The activities of her salon are also discussed in Jacques Lavaud, Philippe Desportes (1546-1606): un poète de cour au temps des derniers Valois (Paris: Droz, 1936), 72-106, L. Clark Keating, Studies on the Literary Salon in France, 1550-1615 (Cambridge: Harvard University Press, 1941), 103-125, Jeanice Brooks, "La comtesse de Retz et l'air de cour des années 1570," in: Le concert des voix et des instruments à la Renaissance, ed. Jean-Michel Vaccaro (Paris: Editions du CNRS, 1995); and Rosanna Gorris, "Je veux chanter d'amour la tempeste et l'orage': Desportes et les Imitations d'Arioste," in : Philippe Desportes (1546-1606): Un poète presque parfait entre Renaissance et Classicisme, ed. Jean Balsamo (Paris: Klincksieck, 2000), 173-211. 
translation was the result of a commission. ${ }^{18}$ Three years later, Anthoine Tiron's translation of the Quatorsieme livre was published with a preface by Gohory dedicating the volume to Henriette de Cleves, duchesse de Nevers, one of Catherine de Clermont's greatest allies at court. ${ }^{19}$

In the same years, the countess was closely connected to seminal French music prints devoted to the nascent genre of the air de cour. Catherine de Clermont was a dedicatee of Guillaume Costeley's Musique of 1570, the first music print to employ the word air to describe vernacular strophic songs. ${ }^{20}$ More significant still is Adrian Le Roy's dedication to her in the following year of his Livre d'airs de cour miz sur le luth, the first printed music collection to designate such songs as airs de cour. ${ }^{21}$ The Livre d'airs de cour contains versions for voice and lute of fashionable court songs, most of which had previously been published in polyphonic arrangements in Nicolas de La Grotte's Chansons of 1569. In his preface, Le Roy points out that Catherine already knows their melodies and texts, and he suggests that their familiarity will contribute to her pleasure when she performs these new versions on the lute. ${ }^{22}$ The Livre d'airs de cour was a sequel

18 Gohory was responsible for Le Dixiesme livre d'Amadis de Gaule and L'Onzieme livre d'Amadis de Gaule (Paris: Groulleau, Longis \& Sertenas, 1552 and 1553); his translation of the thirteenth book was the first new volume to appear since Guillaume Aubert's 1556 translation of book 12. On Gohory's biography, see the list of sources supplied by Rosanna Gorris, "Pour une lecture stéganographique des Amadis de Jacques Gohory," in: Les Amadis en France, ed. Aulotte, 127-156.

${ }^{19}$ Le quatorzieme livre d'Amadis de Gaule, trans. Anthoine Tiron (Chambéry: Poumar, 1575); on the friendship between Catherine de Clermont and Henriette de Clèves, see Lavaud, Philippe Desportes 89-90 and 93; Jeanice Brooks, Courtly Song in Late Sixteenth-Century France (Chicago: University of Chicago Press, 2000), 109-110.

20 Guillaume Costeley, Musique de Guillaume Costeley, organiste ordinaire et vallet de chambre, du treschretien et tresinvincible Roy de France (Paris: Le Roy \& Ballard, 1570), partly edited in Henry Expert, ed., Les maîtres musiciens de la Renaissance française (Paris: Leduc, 1894-1908; reprint, New York: Broude Brothers, n.d.), vol. 18 (1896); for pieces missing from Expert's edition see Jane Bernstein, ed., The Sixteenth-Century Chanson, 30 vols. (New York: Garland, 1987-95), vol. 8 (1989). Catherine's husband Albert de Gondi was another dedicatee of Costeley's Musique, and in the same year he received a dedicatory ode by Adrian Le Roy in Orlande de Lassus, Mellange d'Orlande de Lassus, contenant plusieurs chansons, tant en vers latins qu'en ryme françoyse (Paris: Le Roy \& Ballard, 1570), reedited as Meslanges d'Orlande de Lassus (Paris: Le Roy \& Ballard, 1576). See Brooks, "La comtesse de Retz;" a complete list of dedications to the Retz appears on pp. 313-314. Gondi was the premier gentilhomme de la chambre in the last years of the reign of Charles IX (d. 1574), a position of great power that helps to explain the rash of literary dedications to him and his wife in the early $1570 \mathrm{~s}$.

${ }^{21}$ Adrian Le Roy, Livre d'airs de cour miz sur le luth (Paris: Le Roy \& Ballard, 1571), in Lionel de La Laurencie, Adrienne Mairy, and Geneviève Thibault, eds., Chansons au luth et airs de cour français du XVIe siècle, ed. Lionel de La Laurencie, Adrienne Mairy, and Geneviève Thibault (Paris: Société Française de Musicologie, 1934; reprint, 1976).

${ }^{22}$ For a detailed discussion of the book see Brooks, Courtly Song, 13-31. Its relationship with Nicolas de La Grotte, Chansons de P. de Ronsard, Ph. Desportes et autres (Paris: Le Roy \& Ballard, 1569) is analyzed in Jonathan Le Cocq, "The Status of Le Roy's 
to another book Le Roy had recently dedicated to Catherine de Clermont, a lute instruction, probably first printed in 1570, which survives only in a 1574 English translation. ${ }^{23}$ In the preface to the Livre d'airs de cour, Le Roy identifies himself as a "hereditary servant" of Catherine's family. The allusion is clarified by a passage in the preface to the lute instruction, in which Le Roy evokes his service to Catherine's father, Claude de Clermont, baron de Dampierre, and recalls how he wept over Dampierre's body when he was killed in battle in $1545^{24}$

This long-standing association suggests that songs from several other books by Le Roy formed part of Catherine's repertoire. Soon after Le Roy and Robert Ballard founded their music printing firm in 1551, they published a series of books devoted to music for plucked string instruments which identify Le Roy himself as the author of the tablatures. Among these was the Second livre de guiterre, contenant plusieurs chansons en forme de voix de ville, first printed in late 1551 or early 1552 and devoted to strophic song. It presents versions for guitar and voice of pieces that Le Roy \& Ballard simultaneously printed in polyphonic arrangements in Pierre Certon's Premier livre de chansons of $1552 .^{25}$ As Table 1 demonstrates, Le Roy repeatedly turned to these songs as both printer and arranger over the next two decades. Shortly after dedicating the Livre d'airs de cour to Catherine in 1571, Le Roy produced his Premier livre de chansons en forme de vau de ville (1573), consisting of new polyphonic arrangements of the same strophic songs he had published in the $1550 \mathrm{~s}$ and $1560 \mathrm{~s}$ in both guitar and polyphonic vocal versions. The books dedicated to Catherine de Clermont in the early 1570 s (whose contents even share a few concordances with the earlier prints) were the most recent manifestations of a career-long interest in music in this style. Le Roy's "hereditary service" to Catherine's family makes it seem likely she heard him perform this music when she was a child; his dedication to her of a lute instruction suggests that Le Roy may even have been her teacher on the instrument. His comments in the preface to the Livre d'airs de cour about Catherine's familiarity with the pieces it contains gesture toward a body of court songs well known to both and frequently played and sung in Catherine's salon. As

Publications for Voice and Lute or Guitar," The Lute 35 (1995): 4-27, and Jonathan Le Cocq, "French Lute Song, 1529-1643" (D.Phil. thesis, University of Oxford, 1997), 11-20.

${ }^{23}$ Le Roy's first lute tutor was probably first published in France in 1567; it survives only in a 1568 English translation. The lute instruction dedicated to Catherine probably appeared in 1570, shortly before the Livre d'airs de cour. Material from all three books was subsequently included in Le Roy's $A$ briefe and plaine Instruction to set all musicke of divers Tunes in Tableture for the Lute (London: Rowbothome, 1574), edited as Adrian Le Roy, Les instructions pour le luth, ed. Jean Jacquot, Pierre-Yves Sordes, and Jean-Michel Vaccaro, 2 vols., Corpus des Luthistes (Paris: Editions du CNRS, 1977); an account of the bibliographical history appears in vol. 1, ix-xiv.

${ }^{24}$ Editions of the 1574 English translation of the preface appear in Ibid., 1:2-3, and La Laurencie, Mairy, and Thibault, eds., Chansons, Ivi.

${ }^{25}$ (Paris: Le Roy \& Ballard, 1555 [1556 n.s.]; this is a second edition of a lost print that was first published between the appearance of the Premier livre de tabulature de guiterre in September 1551 and the Tiers livre de tabulature de guiterre of 1552 . 
has long been noted, all of these prints are central to the history of the type of song once known as voix de ville and rebaptised air de cour by Le Roy in $1571 .^{26}$

One link through the prints connected to Catherine de Clermont's salon in the early 1570 s is Adrian Le Roy, printer of Costeley's volume and author/ arranger of the others. Another was Jacques Gohory, who supplied a Latin dedicatory poem to the Costeley book and a French preface for Le Roy's lost lute instruction, among a series of prefatory poems and dedications he contributed to Le Roy \& Ballard prints in the years around 1570. Gohory was a long-standing acquaintance of Le Roy's as well as an habitué of the Retz salon. In the lute instruction, Gohory wrote that he was inspired by "the affection which from my youth upwards . . . I have borne, to Musicke ... [ [and] the old familiaritie which it hath caused me to have with the Aucthor of this present Booke." ${ }^{27}$ At the end of his preface Gohory mentions another current project that is almost complete: his translation of the thirteenth book of Amadis de Gaule. This was shameless self-publicity, but motivated at least partly by the assumption that purchasers of the lute book will also be interested in reading the romance when the translation is published.

Or at least one reader will be: Catherine de Clermont. To borrow the terminology used by Marian Rothstein in her reception-oriented study of Amadis, Catherine appears as one "manifest reader" of the thirteenth book of Amadis, Costeley's Musique, the lute instruction and the Airs de cour miz sur le luth. ${ }^{28}$ By dedicating these books to Catherine, Le Roy and Gohory construct her as the intended reader and performer of their contents. It is more difficult to identify other readers not explicitly designated by the texts: though Amadis has left greater traces of its readership than most works of the sixteenth century, the music prints have left almost none. Their survival rate is poor, and in sixteenth-century inventories of libraries, notaries generally lumped all music books together under

${ }^{26}$ The songs' wide dissemination is suggested by the inclusion of most of the pieces in the collections listed in Table 1 in Jehan Chardavoine's monophonic compendium of popular voix de ville: Le recueil des plus belles et excellentes chansons en forme de voix de ville, ed. Jehan Chardavoine (Paris: Micard, 1576; reprint, facsimile, Geneva: Minkoff, 1980). The role of these collections in the history of the genre is most thoroughly treated in Jane Ozenberger Whang, "From Voix de ville to Air de cour: The Strophic Chanson, c. 1545-1575" (Ph.D. diss., University of North Carolina, 1981).

${ }^{27}$ Preface included in François Lesure and Geneviève Thibault, Bibliographie des éditions d'Adrian Le Roy et Robert Ballard (1551-1598) (Paris: Société Française de Musicologie, 1955), 33-35. Gohory also supplied dedicatory poetry to three books of Lassus motets: Secundus liber modulorum, quinis vocibus (Paris: Le Roy \& Ballard, 1571), Tertius liber modulorum, quinis vocibus and Moduli sex septem et duodecim vocum (both Paris: Le Roy \& Ballard, 1573), and to Lassus, Mellange, the same chanson anthology that contains Le Roy's poem to Albert de Gondi.

28 "Manifest readers" are those to whom books are dedicated or who appear in its prefatory pages as the authors or recipients of liminary texts. Rothstein, Reading in the Renaissance, 114-117. For other books of the Amadis cycle, they include writers such as Etienne Jodelle and Etienne Pasquier, who were habitués of the Retz salon; their prefatory poems to book 9 are reproduced in Vaganay, Amadis en français, 89-91 and 94. 
rubrics such as "un paquet de livres de musique" without supplying details of individual titles. Nevertheless, ownership marks in the rare extant copies of the song books listed in Table 1 show that their possessors frequently belonged to the same social environment of musicians, writers, court nobles and officials as Costeley, Le Roy, Gohory, Catherine de Clermont and her circle. ${ }^{29}$ Though the information is patchy, it is consonant with what we know about the ownership of Amadis, and confirms that both kinds of books were consumed within as well as generated by courtly milieux.

But the relationships between the Amadis novels and collections of court song are more complex than simply shared readership. Many of the pieces in the song books present lyric meditations on the stereotypical situations of romance, employing the same vocabulary and language as well as position. That is, they are linked not only in a concrete economy of the book market but in the imaginative economy of expression and image. These correspondences in content combine with the strong overlap in production and reception history to suggest that romance supplied frameworks that sixteenth century Frenchwomen themselves brought to understanding song and vice versa, frameworks which we in turn can productively apply to tease out the import of song and romance to a female audience.

In one case, the link between texts is explicit: C'est de la peine dure, a song Le Roy included in both his 1552 guitar book and the 1573 Premier livre en forme de vau de ville, ends with a strophe in which the male speaker compares his loyal service to his lady to that of Amadis to Oriane:

\author{
Vous serez Oriane, \\ Je seray Amadis, \\ Ou bien donc l'Eriane, \\ Qui aima mieux mourir \\ Que changer sa maistresse: \\ Combien que par destresse
}

${ }^{29}$ A collection of superius partbooks in F-Pn Rés. Vmf. 13, which contains copies of the 1564 editions of Certon's Premier livre and the Second livre de chansons, belonged to Louis Cramoisy, a keyboard player in the household of the king's brother François d'Anjou. A set of partbooks from the Cortot collection now in $G B-L B l$ k.11.e. 3 belonged to one of the countesses of La Tillières early in its history; it is not clear from the ownership marks whether this was Charlotte Chabot, who married Jacques de Tillières in 1578, or Catherine de Bassompierre, who married Tanneguy de Tillières in 1608. The Veneur de Tillières were a prominent family of the court nobility; the partbooks include La Grotte's Chansons and the 1569 edition of the Second livre. Le Roy's Livre d'airs de cour survives in a unique example ( $B-B r$ Fétis 2379$)$, which in the early seventeenth century belonged to a prominent Burgundian author and royal official, Hugues Picardet; see Laurent Guillo, "Les livres de musique de Hugues Picardet (1560-1641), procureur général au Parlement de Bourgogne," Bulletin du Bibliophile 1 (2001): 58-85. The poet Rémy Belleau, who dedicated a sonnet to Catherine, and, as a retainer of the Guise family, must frequently have been in contact with her, owned a lute, a cistre and a dozen music books (none individually described by title in his inventory, unfortunately; see Madeleine Jurgens, Documents du Minutier Central des Notaires de Paris: Ronsard et ses amis (Paris: Archives Nationales, 1985), 219 and 32. 
D'amour l'aye fait mourir.

[You will be Oriane,

I will be Amadis,

or perhaps Eriane,

who preferred to die

rather than forsake his lady,

such that the torment

of love caused him to die. $]^{30}$

In another instance, a scene in Gohory's translation of Book 13 of Amadis intersects with the repertory of Costeley's 1570 Musique. Gohory frequently inserted new poems in his Amadis adaptations, lyric additions that represent musical interludes in the text. In Book 13, most of Gohory's songs occur as part of the wedding celebrations that make up the final episodes of the book. During the celebrations, a black female servant "garnie de sonnettes és bras et jambes et sonnant des cymbales, chanta et dança le cantique de l'antique Roine de sa region en son langage" [embellished with bells on her arms and legs and sounding cymbals, sang and danced the ancient canticle of the queen of her country in her own language]. Gohory then presents a verse adaptation of the Queen of Sheba's text from the biblical Song of Solomon, followed by a short response for Solomon himself. In Costeley's music collection, Que de baisers de sa bouche is a very similar French verse adaptation of the same text set as a simple strophic song. ${ }^{31}$

But more significant for my purposes than such explicit references or obvious parallels are instances in which song texts in the orbit of the Retz salon appear to elaborate characteristic situations of the novels and mirror moments of their characters' speech. Their resonance is clear across a range of lyric types, including songs employing feminine subject voices. The violently contested territory occupied by women's speech in this period makes these moments where feminine subjects speak or sing particularly revealing of contemporary views of female sexuality.

In the Amadis novels, women characters speak about their feelings in scenes that are repeated with minor variations throughout the cycle. Struck - usually at first sight - by love, they express their longing for the beloved; but, in the central relationships at least, sexual consummation almost always faces formidable obstacles. Knights errant have an unfortunate propensity for rushing off in search of adventure, and women's laments on their lovers' departures or reported deaths are common. But an even more significant impediment than separation is the

${ }^{30}$ For a modern edition of the vocal setting see Bernstein, ed., SCC, 15: 23-25.

${ }^{31}$ Amadis XIII, fols. 336r-337r; Bernstein, ed., SCC, 8: 132-34. Gohory starts with v. 5 of the Song of Solomon; the poem set by Costeley begins with v. 2 of the biblical text, reaching v. 5 in the third strophe. Though the rhyme schemes differ (that set by Costeley is rimes plates, while Gohory uses interlocking rhyme), both poems use quatrains of 7-syllable lines, and the opening of Gohory's text ("Filles de la cite saincte") is the same as the beginning of Costeley's strophe 3 . 
social constraint represented by the concept of honor. Dialogues with male characters often involve women's vigorous defense of honor against masculine pleading for its relaxation. Yet their resistance is usually in contradiction to the women's own wishes, and another topic of lament is the rigors of honor that prevent women from satisfying needs they describe as equal to those of their suitors. In the end, the woman is almost invariably conquered by the male character's unsurpassed virtues and her own passion. The lovers finally have sex, portrayed as mutually willed and mutually satisfying. Though they often exchange vows of fidelity or make marriage promises beforehand, much of the sexual activity in the novels takes place outside formal marriage structures. Even when the result is an illegitimate child, such encounters are regularly presented as virtuous; in relationships like those between Amadis and Oriane, erotic love is equated with exceptional moral and physical strength. ${ }^{32}$

In the standard romantic procedure, these exemplary encounters are counterbalanced by negative models, through episodes where women have chosen their lovers unwisely or yielded too quickly to libidinous impulse. Such women frequently lament their misfortune and make bitter accusations against the faithless men; in other cases, the text may allow the couple to take pleasure in sex and separate without any emotional or other consequences. And while successful or unsuccessful heterosexual relationships provide the majority of the material, Amadis also provides frequent glimpses of other sexualities through autoerotic or homosocial episodes, the latter usually (though not inevitably) involving crossdressed women or Amazons who play a masculine role in relation to another woman. ${ }^{33}$

The range of erotic effects and potential outcomes is thus fairly wide, but feminine desire is represented in similar ways in virtually all situations. Women articulate erotic feelings only in private, to confidantes, lovers or to themselves, and in letters (whose potential interception is often an explicit cause for concern). Lovers' meetings always take place in secret, for they are aware that the society around them is likely to condemn their relationship as illicit despite its blamelessness in the divine order. Women's speeches frequently evoke the need to

32 As Marian Rothstein has remarked, "Herberay's Amadis . . . generally considers consensual sex between nobles as a laudable activity whose results, often male offspring, were generally pleasing to God in the great scheme of things." Rothstein, Reading in the Renaissance 138. The attitude is common in medieval romance, and here receives a Neoplatonist spin; the physical union of faithful lovers partakes of the spiritual union that is a prerequisite for divine revelation. These attitudes are most typical of the vein of Neoplatonist erotic spirituality represented by Leone Ebreo, whose Dialoghi d'amore (1535) was widely disseminated in French translation.

33 Some such encounters are discussed in Winfried Schleiner, "Laughter and Challenges to the Other in the French Amadis de Gaule," Sixteenth Century Journal 32 (2001): 91-107, and idem, "Le feu caché: Homosocial Bonds Between Women in a Renaissance Romance," Renaissance Quarterly 45 (1992): 293-311; a musical crossdressing episode from Book 11 (in which two adolescent males disguise themselves as female lute-singers) is the topic of a study of my own, currently in preparation. 
suffer love in silence, to conceal their passion from the outside world and often even from the beloved. Discretion is valued in male characters, but because their disclosure of the relationship will endanger the woman's reputation, not their own.

In other words, female sexuality is rhetorically figured as silence, something not to be spoken; the speaking subject allows readers to appreciate her desire only in terms of what is withheld from most or all of the other characters of the text. Well-born women that they are (and they invariably are in Amadis), they express their wishes to conform to contemporary feminine ideals. In conduct books of the period, silence was usually cast as a central female virtue, the restraint of a woman's mouth a corollary to restraint of her body and a sign of her unblemished chastity. Many courtly texts, in contrast, aim to rehabilitate female speech in contexts particularly relevant to women of the elite class: conversation in courtly gatherings, displays of verbal proficiency by women rulers. Yet such texts were also obliged to confront the persistent conflation of female speech and sexual activity in contemporary culture, and are careful to circumscribe women's verbal activity in ways that preserve sexual reputation. ${ }^{34}$ The interdiction on speaking of desire resonates too with the Neoplatonic aim of rational control of the body as an ideal for both sexes, and with the socialization of Neoplatonic theory projected by Castiglione and later imitators, with its emphasis on dissimulation as part of a quintessentially courtly aesthetic. In lamenting the constraints of honor and in speaking about silence, women's voices in Amadis simultaneously invoke and disrupt these controls on their own utterance.

When we turn to books of airs, we find that feminine musical voices often echo instances of speech in the novels. Women's laments on abandonment, separation or the death of a lover appear in several of the song collections; a good example is Mon coeur ma chere vie, a poem possibly by Catherine de Clermont herself, included in musical setting in Le Roy's Livre d'airs de cour. Laments such as this participated in a much wider culture of female mourning: the topos of lament could be manipulated as a tool of female agency in a variety of social and political contexts. ${ }^{35}$ And lament could also be a mode of articulating desire, a role it frequently serves in both novel and song. For example, the singer of $O$ la mal assignée, included in Le Roy's 1552 guitar book and 1573 Premier livre de chansons en forme de vau de ville as well as all the editions of Certon's Premier livre, mourns a lover who has been killed by a jealous rival in an ambush of their tryst. As in other laments, she predicts her own imminent demise from grief; but

34 For a more detailed discussion of these issues and their impact on women's speech and song at court, see Brooks, Courtly Song, 191-254.

35 See the 1999 special issue of Early Music devoted to women's laments in the sixteenth and early seventeenth centuries. Jeanice Brooks, "Catherine de Médicis, nouvelle Artémise: Women's Laments and the Virtue of Grief," Early Music 27 (1999) in that issue and Brooks, Courtly Song, 209-227, deal in detail with Mon coeur ma chere vie in the context of Catherine de Médici's political agenda. Further on the political uses of lament see Kate van Orden, "Female Complaintes: Laments of Venus, Queens, and City Women in Late Sixteenth-Century France," Renaissance Quarterly 54 (2001): 801-845. 
here she weeps not only for the loss of her lover but for the disappearance of her hopes of sexual pleasure. In the final strophe of the poem she says that the kisses she lavishes on the corpse cannot replace the sex she had expected from their meeting:

\author{
Bouche que je te baise \\ Cent foys la baiseray, \\ Ce baiser ne m'appaise \\ J'attendoye plus grand' aise \\ Que jamais je n'auray. \\ [Mouth, let me kiss you, \\ I will kiss you a hundred times, \\ this kiss does not appease me, \\ I awaited a greater pleasure \\ that I will never have.]
}

Women's laments as a mode of expressing longing and describing the effects of desire abound in the Amadis novels; these are among the lengthiest and most emotionally vivid speeches of the female characters, and were also frequently among those extracted for the collections of Thresors. Examples include Oriane's lament in Book 2, in which she compares the desolation of her waking life without Amadis to the joy of his nocturnal visits in her dreams; or Lucelle's in Book 8, in which she contrasts her current bitterness over her lover's deceit with the pleasures they enjoyed before. A telling example of sung lament as vehicle of desire, one with close parallels in Amadis, is Est-ce pas mort. The song first appeared in Adrian Le Roy's polyphonic arrangement in the revised edition of the Second livre de chansons, published in 1564 and reedited in 1569 and 1577 (see Appendix 1). The poem was widely distributed in text-only chansonniers in the $1570 \mathrm{~s}$ and $1580 \mathrm{~s}$ under the rubric "Complainte de l'amoureuse craintive mourant d'amours" [lament of the fearful amorous woman dying of love]. ${ }^{36}$ Here the lament turns on the conflicts between desire and honor, between the urge to speak and the inability to do so. These tensions have brought the singer to the erotically charged state of near-death evoked in the refrain, "Amour pense que je dors et je me meurs." Her depiction of the physical consequences of thwarted desire echoes Marfire's situation in Book 13 of Amadis (see Appendix 2); her description in strophes 11-12 of masturbation as substitute for the imagined caresses of a lover is similar to a passage in Book 1 (see Appendix 3). But perhaps the most striking resemblance is to Sidere's lament in Book 13 (see Appendix 4), for Sidere too has been prevented from yielding to passion by her fear of loss of reputation, and regrets her lack of courage in not speaking to her suitor Rogel to arrange an assignation. Like the

${ }^{36}$ For example, in the Sommaire de tous le recueils de chansons, tant amoureuses, rustiques que musicales (Lyon: Rigaud, 1579), fols. 61r-62r. For earlier appearances of the text in such chansonniers, see Kate van Orden, "Vernacular Culture and the Chanson in Paris, 1570-1580" (Ph.D. diss., University of Chicago, 1996), 248. 
singer of Est-ce pas mort, Sidere rails against honor, which she characterizes as the "executioner and murderer" of love-sick women. ${ }^{37}$

Other laments emphasize the masochistic pleasures to be derived from the tensions between desire and honor. The most venerable was probably the musical setting of Mellin de Saint-Gelais's $O$ combien est heureuse, which like $O$ la mal assignée, figured in Le Roy's and Certon's books of voix de ville from 1552 through 1573. Saint-Gelais was a friend of Herberay des Essarts and contributed liminary poetry in his honor to Amadis; when assuming a feminine subject voice (a gender ventriloquism the poet often adopted in his lyrics), Saint-Gelais created characters who might easily have stepped from the pages of the novel. The speaker of $O$ combien est heureuse is a good example. Frustrated by the imperative of concealment, she asks her lover to show her that his ardor is as great as hers, which she describes as "violent," "hot," and the cause of unending jealous torment when, out of discretion, her lover speaks with other women and not with her. Yet as she declares from the outset, these tortures are pleasing as a variety of amorous foreplay:

O combien est heureuse

La peine de celer

Une flamme amoureuse

Qui deux coeurs fait brusler,

Quand chacun d'eux s'attend

D'estre bien tost content.

[O how delightful is

the pain of concealing

an amorous flame

that makes two hearts burn

when each of them expects

very soon to be content.]

$O$ combien est heureuse was one of Saint-Gelais's most famous poems (it even came in for specific condemnation from the poets of the Pleiade, whose antipathy for this sort of lyric was notorious) and in its musical setting it was extremely widely disseminated; already well-known when Le Roy began publishing it in 1552 , by the heyday of Catherine de Clermont's salon in the early 1570 s, it surely counted as an old chestnut. A similar, but more up-to-date case was Philippe Desporte's poem Ah Dieu que c'est un estrange martyre, printed in polyphonic setting for the first time in Nicolas de La Grotte's 1569 Chansons and

${ }^{37}$ Texts such as this appear to contradict van Orden's assertion that "essentially, [sixteenth century] lyric assigns erotic longing to men and mourning to women" (van Orden, "Female Complaintes," 801). As these examples show, the categories of lament and erotics were not mutually exclusive. Pamela Coren points to similar cases in English lute song, where "grief is being used as a vehicle for the ardour of love complaint" ("Singing and Silence: Female Personae in the English Ayre," Renaissance Studies 16 (2002), 538). 
then included in lute arrangement in Le Roy's Livre d'airs de cour. Desportes was closely involved with Catherine de Clermont's circle, and would distinguish himself in the $1570 \mathrm{~s}$ and $1580 \mathrm{~s}$ as the poet most often set to music in collections of strophic song. ${ }^{38}$ Ah Dieu que c'est un estrange martyre is a Neoplatonic dialogue in which the woman speaker's strophes alternate with those of her lover. Both chafe at the restrictions that prevent them from speaking with each other in public, but as in $O$ combien est heureuse, the interdiction on speech is a stimulant rather than a damper to desire. As the female interlocutor exclaims in her first strophe:

Le feu couvert a plus de violence

Que n'a celuy qui ses flammes eslance

L'eau qu'on arreste en est plus irritée

Et bruit plus fort plus elle est arrestée.

[The smothered fire is more violent

than one that throws out its flames,

water that is dammed up is more furious as a result

and the more it is stopped the more it clamors.]

In Book 12 of Amadis, Diane uses the same metaphor in a lament addressed to her absent lover Agesilan. Honor prevents her from declaring her love publicly in such a way that the news of it will reach him while he is gone; but the act of concealment only increases her passion: "les [mes douleurs] tenans cachées de jour en jour je sens accroistre leur felonnie dans mon courage, en la façon que le feu estroictement reserré dans la fournaise redouble continuellement ses forces" [keeping my sufferings hidden, from day to day I feel their crime against my courage increase, in the way that the fire tightly closed up in the furnace continually redoubles its strength]. ${ }^{39}$

The link between all these expressions of female erotic longing is the consistent dialectic with the regulatory notion of honor and its demands. In one song, L'amour avec l'honneur, the combat between love and honor is thematized; the battle the speaker describes as taking place in her heart happily ends in a truce brought about by Nature, and the lyric functions as a mode of reconciling desire and honor as well as a site for dramatizing their conflict. ${ }^{40}$ In Book 9 of Amadis this metaphorical battle for the woman's body is translated into an actual war

${ }^{38}$ On Desportes's association with Catherine, see Lavaud, Philippe Desportes, 100 101; for an index of his poetry set to music, see André Verchaly, "Desportes et la musique," Annales musicologiques 2 (1954): 271-345.

${ }^{39}$ I cite the text here as it appears in Tresor de tous les livres d'Amadis de Gaule. . . pour instruire la jeune noblesse Françoise à l'eloquence, grace, vertu et generosité (Lyon: Hugueton, 1582), fol. $218 \mathrm{v}$. The image of the banked fire is a lieu commun in this literature, but that is precisely the point; the repetition of a limited range of metaphors in songs and novels reinforces their similarities in language and register.

${ }^{40} L$ 'amour avec l'honneur appears in Le Roy's collections of 1552 and 1573, and all editions of Certon's Premier livre. 
between two armies, though here the battle is so inclusive and the casualties so numerous that the result is somewhat less satisfactory.

Motives for the obsessive repetition and elaboration of the theme of love versus honor in romance and related lyric genres are not difficult to find. Female characters' resistance to masculine assaults on their honor allow the love episodes to be constructed as quest plots parallel to those of the battle narrative; the more vigorous and prolonged a woman's defense, the more praiseworthy is the hero's eventual victory over her scruples. Yet there are also distinct advantages for women in this formulation; in a narrative when most women - with the exception of the Amazons and warrior maidens - are barred from participation in the real business of war, the tensions between love and honor allow them to become the heroines of an interior battle with emotion and will, metaphorically exercising the same courage and determination as the male characters in armed combat. Similarly, the mode of lament allows women to adopt the Petrarchan positions of unfulfilled longing usually occupied by masculine subjects. ${ }^{41}$ Yet the concomittant imperative of concealment that invariably accompanies women's articulation of erotic wishes marks their experience of desire as radically different from men's. As Cormelie exclaims to Esplandian in Book 5 of Amadis:

Par mon ame je congnois bien maintenant que l'affection et amour des hommes est bien differente aux passions que nous autres simples femmelettes endurons quand nous tombons en ceste extremité: et ş̧avez vous en quoy? Vous hommes prenez communement plaisir à manifester ce que vous aymez, soit par parolles ou par contenance: ... qui est bien le contraire du naturel des femmes (j'entens celles qui se peuvent nommer sages et prudentes) car tant plus elles sont hautement apparentées, et plus ont de craincte que l'on apperçoive leurs passions amoureuses, de sorte qu'elles nient ordinairement de paroles, de gestes, et de contenance, ce qu'elles ont plus imprimé en leur coeur et esprit. ${ }^{42}$

[By my soul I now know well that that the affection and love of men is very different from the passions that we poor simple little women suffer when we fall into that extremity: and do you know in what way? You men all take pleasure in showing, whether in words or in your countenance, that you love: . . . which is the opposite of the natural disposition of women (I mean those who can call themselves well-behaved and prudent) for the more they are highly born, the more they fear that their amorous passions will be detected, so that they regularly deny, with words, gestures and looks, that which they have most deeply imprinted in their hearts and souls.]

Honor, that is, is so constant an accompaniment to the desires of noblewomen as to effectively become part of them; women's erotic feelings are so inevitably marked

${ }^{41}$ In one case, Sidonie's complainte in Book 11 of Amadis, the female character even laments in the form of a sonnet modelled on Petrarch, although the poem's structure is camouflaged by the layout of the text as prose (rather than the indented italics used for other lyric insertions in the romance). See L'onziesme livre d'Amadis de Gaule (Paris: Groulleau, 1560), fol. IIv.

${ }^{42}$ Text cited from the Tresor de tous les livres d'Amadis, fols. 105r-105v. 
by fear that Cormelie can essentialize these emotions as a product of women's "natural disposition."

These relationships between musical texts and chivalric romance can be construed in several complementary ways. The volumes of "treasures" of Amadis - collections of favorite extracts that allowed speeches of the book to survive independently of their framing narrative - suggest one possibility; we might think of song books as kind of lyrical Thresor, a mode of crystalizing characteristic romantic moments in a different form. Another productive comparison involves the tradition of lyric insertions in romances, a practice with a pedigree stretching back into the middle ages. Different manuscripts of medieval romances have different insertions, or none at all; lyric, with or without musical notation, was never an essential component of romance, but a common embellishment to it. We might understand some pieces in sixteenth century song books as providing a lyric embroidery to romance separated by print medium, and we might think of romance as providing a narrative scaffold within which such songs make sense. That is, for sixteenth century audiences, chivalric romance could supply motives and stories for the emotional situations in which women singers find themselves, stories that licensed the vocal representation of female sexuality in particular modes and styles. In both these interpretive scenarios, the function of song is to distill romance into its emotional essence, rendering its impact more forceful through the expressive power of music. In this, sixteenth century airs prefigure the role Crystal Kile has outlined for modern popular love songs: "In the typical pop love song, the prescribed brevity of the form combines with the intense affectiveness of music and the constructed emotional ultimacy of romantic love to create an almost orgasmic, ecstatic 'perfect love moment' or a moment of 'perfect romantic despair' over love." And while creating these "perfect romantic moments," airs evoked the narratives of romance that gave rise to the emotional states exemplified in the songs.

Such relationships may seem obvious when we consider the closest sixteenth century Italian parallel, Ariosto's Orlando furioso, and its musical manifestations. (It is worth noting here that the Retz salon was a prime site for the translation and adaptation of Ariosto at the same time it was filling that role for Amadis. ${ }^{44}$ ) But scholars have been much slower to look to romance as a tool for understanding the place of song in early modern France, perhaps partly because the relationship between prose romance and sung poetry is less easy to grasp than the direct setting in music of sections of a verse romance such as Orlando furioso. The traffic between prose and sung poetry required contexts that encouraged the circulation of

${ }^{43}$ Crystal Kile, "Endless Love Will Keep Us Together: The Myth of Romantic Love and Contemporary Popular Movie Love Themes," in: Popular Culture: An Introductory Text, ed. Jack Nachbar (Bowling Green, OH: Bowling Green State University Popular Press, 1992; reprinted in Weisser, ed., Women and Romance), 419.

${ }^{44}$ See Lavaud, Philippe Desportes, 101, and Gorris, "Je veux chanter;" Rothstein, Reading in the Renaissance, 37 and 110-114, compares narrative procedures in Ariosto and Amadis. 
image and style between genres. It seems clear that Catherine de Clermont's circle provided one such environment. And the salon also acted as a frame in which female audiences (conceived broadly in terms of women readers, singers and listeners) interacted with the images of noblewomen populating this nexus of musical and literary texts. That men wrote the novels, and most (though probably not all) of the poetry and music - with masculine needs and goals as the principal motor - has perhaps obscured their potential use by real women as a mode of creating and enriching their own erotic lives, in contexts where performance could serve as a vehicle for agency. ${ }^{45}$

As a starting point, we might consider how women read the Amadis novels. In an acute analysis of the reading strategies built into the text itself, Marian Rothstein has observed that the romance pushed readerly participation in the realization of the text to hitherto unknown limits. These tactics are especially apparent in the sexual encounters, where explicit description is replaced by appeals for readers to furnish whole scenes from the resources of their own experience and imagination. Herberay des Essarts employed this technique from the outset, and subsequent translators, including Gohory, followed his lead. ${ }^{46}$ In some instances women are the only readers competent to fill in the textual gaps; for example, female experience is expressly solicited in the account of the night Agraies and Olinde spend together in Book 1:

Adonc furent embrassemens et baisers par milliers: adonc caresses et tous bons traictemens que deux amans (en liberté) se peuvent faire, furent en saison, et tant que l'execution de l'amour s'en ensuiyvit la nuict mesmes, dont il advint que la gentille

${ }^{45}$ Susanne Rupp's work with English song and poetry has been influential in developing my ideas on this topic; see Rupp, "Silencing und Empowerment: Stimme, 'performance' und gender bei Sir Philip Sidney und Thomas Campion," in: Sister Arts: Englische Literatur im Grenzland der Kunstgebiete, ed. Joachim Möller (Marburg: Jonas, 2001), 29-37. Coren, "Singing and silence," argues that the female personae of English ayres were largely reductive fantasies aimed at the male readers who were the primary audiences for the repertory, but remarks (p.546) that they nevertheless offered multiple opportunities for appropriation or resistance by women, to whom they might suggest "ways out of silence."

${ }^{46}$ A typical example from the Trezieme livre: "Et pour clorre et sceeler ce bon appointement [Sidere and Rogel] s'entredonnerent maints autres gracieux baisers jusques à ce qu'ils apperceurent les tenebres faillir qui les contraignoient de se retirer chacun en sa chambre, jusques à la nuit ensuivant qu'ils s'y trouverent encore et par deux autres semblablement en tel plaisir et soulas que tous amoureux peuvent imaginer par leur experience." [And to close and seal this agreement, Sidere and Rogel gave each other many other gracious kisses until they perceived the darkness fading, which obliged them to return each to their own rooms, until the following night and two other nights afterward when they found each other again in such pleasure and relief that all lovers can imagine from their own experience (emphasis added). Amadis XIII, fol. 312v. See Rothstein, Reading in the Renaissance, 107-110, for an analysis of the technique and a series of similar examples taken from the Premier livre. 
damoyselle en perdit le nom de pucelle, avec tel contentement que celles qui semblable ont essayé, et non aultres, peuvent estimer. ${ }^{47}$

[Then embraces and kisses by the thousands: then caresses and all the good treatment that two lovers in freedom can give each other, were in season, and so much that the act of love followed from it that same night, and the noble maiden lost the name of virgin from it, with such pleasure as only those women who have tried the same, and no others, can guess (emphasis added).]

In addition to the novel's calls for women to create sections of the narrative by introducing their own experience into its frame, contemporary reading habits encouraged them to perform the text in sound by reading aloud. This was a common aristocratic leisure practice in the period, and there are several extant accounts of people reading passages of Amadis out loud to others. It seems unlikely that Gohory's translation of Book 13 in particular was not read in this way in the chambers of the woman to whom it was dedicated. Both Marfire's and Sidere's laments from Book 13 referred to above in comparison to Est-ce pas mort were considered striking enough to be included in editions of the Thresors, so if any passages were read aloud in the Retz salon and elsewhere, these were. ${ }^{48}$

If Amadis solicited female readers in ways that encouraged, even demanded their participation in the novels' textual and sonic realization, music prints called for even greater engagement as scripts for performance. As sets of partbooks or arrangements in the gestural notation of tablature, the music the books contain is unintelligible, inaccessible as music without the intervention of a performer to realize it in sound. Adrian Le Roy testifies in his dedication of the Livre d'airs de cour that Catherine herself could perform the pieces. The princess Marguerite de Valois, who with Henriette de Clèves figured among Catherine's closest friends, was also apparently an accomplished performer. Brantôme (who was Catherine's cousin, and the brother of one of Marguerite's ladies-in-waiting) described Marguerite's talents as singer and lute player, and further testified that she wrote her own poetry and set it to music as song. ${ }^{49}$ The musical style of these songs - as in the Musical Example 3.1, Est-ce pas mort - was especially well-adapted to the musical skills of aristocratic women. Relatively simple, often dance-based, and particularly suitable for performances with lute or keyboard (instruments heavily favored for female executants), airs were especially good at creating the

47 Giraud and Vaganay, eds., Amadis I, 194.

${ }^{48}$ For evidence that reading aloud was a feature of aristocratic leisure, see Keating, Studies, and several of the essays in Olivia Rosenthal, ed., A haute voix: diction et prononciation aux XVIe et XVIle siècles (Paris: Klincksieck, 1998). For specific instances of the reading aloud of Amadis see Rothstein, Reading in the Renaissance, and Simonin, "La disgrâce"; Gohory's preface to Amadis XIII reports that François I frequently had the book read aloud to his gentlemen-in-waiting.

49 Pierre de Bourdeille, seigneur de Brantôme, Oeuvres, ed. Ludovic Lalanne (Paris: Renouard, 1864-82), 7:82. 
atmosphere of feminine grace so highly recommended in courtly manuals. ${ }^{50}$ While there is no documentary confirmation that the female members of the Retz salon performed the songs in feminine subject voices that appear in song books arranged by Adrian Le Roy, the circumstantial evidence - of their own performing skills and their familiarity with the poets and musicians who brought the repertory into print - is again so strong as to make it seem very likely that they did.

And when they spoke romances and sang courtly airs, how was their relationship to these texts construed? The open-ended nature of the Amadis novels - the most participatory and closure-resistant literature of the period - encouraged readers to identify with its principal characters. Female readers of Amadis could position themselves in ways similar to those Stevi Jackson sees as characteristic of consumers of modern-day mass market romance, who rely upon the narratives of romance in constructing their own narratives of self. ${ }^{51}$ The sixteenth-century version of this phenomenon was particularly strong, however, and much more overtly acknowledged than in today's culture. There is ample evidence that aristocratic Frenchwomen regularly assumed or were cast in the roles of romantic heroines. Marguerite de Valois was repeatedly likened to Niquée, a central character of the Amadis novels. ${ }^{52}$ Gohory compared Catherine de Clermont to Pentasilee, one of the heroines of Book 13, in his preface to his translation, and as Rosanna Gorris has shown, in several places Gohory figures the real Catherine as Pentasilee in the same way that he writes himself into the book as the tutor of the hero Sylves de la Selve. ${ }^{53}$ That Catherine and other female members of the Retz circle embraced such roles seems confirmed by their adoption of romantic pseudonyms, employed by the women themselves in correspondence and in poetry written in their honor by writers of both sexes. Catherine herself went by the names Dictynne or more frequently, Pasithée; the latter is especially similar to names in Amadis such as Pentasilée. ${ }^{54}$ This process of "becoming" a romantic heroine had particularly strong implications for female vocality, because the central role of Amadis as model for speech encouraged female readers to create new utterances in the style of the novel, using its vocabulary and images as tools for their own expressive needs and blurring the boundaries between the worlds of the novel and of its courtly performative milieux. ${ }^{55}$

${ }^{50}$ For a more detailed discussion, see Brooks, Courtly Song, 198-201.

51 Jackson, "Love and Romance," 260.

52 Rothstein, Reading in the Renaissance, 121.

${ }^{53}$ Rosanna Gorris, "Pour une lecture stéganographique," 151-154; in his translation of Book 11, Gohory had similarly conflated his dedicatee Diane de Poitiers with the heroine Diane de Guindaye (Ibid., 132-150).

${ }^{54}$ Lavaud, Philippe Desportes $88-93$ provides a list of pseudonyms from the salon and identifies the women to whom they were applied. Catherine frequently used these pseudonyms to refer to herself in correspondence with Henriette de Clèves (for an example, see Jullien de Pommerol, Albert de Gondi, 204).

${ }^{55}$ On the term "vocality," see the introduction to Leslie C. Dunn and Nancy A. Jones, eds., Embodied Voices: Representing Female Vocality in Western Culture (Cambridge: Cambridge University Press, 1994). Paul Zumthor has argued for its use in medieval studies 
Similarly, contemporary ideals of musical performance encouraged women singers to inhabit the roles created by the texts and to convince listeners of their own investment in its emotional content. The Orphic image of the listener carried away, completely at one with the passions of the text and music as presented by the supremely inspired singer, is the most widely employed descriptor of successful musical performance in this period. Catherine herself figures as female Orpheus in contemporary poems. Describing the musical powers of "Pasithee," Pontus de Tyard claims that the sound of her lute could render beasts humane and restore joy to the most anguished souls. ${ }^{56}$ Le Roy's Livre d'airs de cour begins with a setting of Le ciel qui fut grand donneur, a song whose prominent position suggests it is addressed to Catherine, the book's dedicatee. The poem, by Jacques de La Chastre, seigneur de Sillac, includes a strophe comparing the lady's voice to the harp of Orpheus, capable of moving the poet's heart, body and soul wherever it chooses. ${ }^{57}$ And there is one fascinating account of a musical performance by Catherine in which her audience understood her to use a lament to express her own yearning for an absent lover. This is an anonymous text in Catherine's poetry album, a manuscript copied for her during the years 1573-75, just after the publication of the song and lute books dedicated to her by Adrian Le Roy ${ }^{58}$ The poet describes how she played the lute, her "secret sighs" translating her longing into audible musical performance:

Encor n'est ce tout l'heur que j'eus aupres de vous, Oyant pinser le luth en ces acors si doux, Quand de soupirs secrets, les yeux levez en haut, La teste mi-baissée, et l'ame en son defaut, Vous sembliez regreter une absence lointaine. ${ }^{59}$

[And this is not all the joy I had in your presence, hearing [you] strum the lute in those chords so sweet, when with secret sighs, your eyes lifted up, your head half-drooping, and your soul faltering, you seemed to regret a faraway absence.]

Paradoxically - and I will return to this point below - the silence and secrecy this text and others repeatedly emphasize as a central component of noblewomen's experience of desire here takes a sounding form that others may hear and interpret.

to draw attention to the role of the human voice in the composition, production and reception of texts. Here I concentrate particularly on the last two elements.

${ }^{56}$ Pontus de Tyard, Oeuvres poétiques complètes, ed. John C. Lapp (Paris: Société des Textes Français Modernes, 1966), 224-226; see also Brooks, "La comtesse de Retz," 308.

${ }^{57}$ See Brooks, Courtly Song, 37-38, for the text.

${ }^{58}$ On the dating and content fr. 25455, see Lavaud, Philippe Desportes, 82-93, Keating, Studies, 107-123, and Brooks, "La comtesse de Retz." St-John, "The Salon vert," contains extensive transcriptions from the manuscript.

${ }^{59}$ F-Pn fr. 25455, fol. 66r. 
The relationship of song prints to musical practice was considerably looser than for more complex Masses, motets and polyphonic chansons, allowing for solo instrumental or vocal adaptation and rendition as accompanied or selfaccompanied song as well as polyphonic performance, and inviting embellishment of vocal lines and accompaniments. The flexibility of performance practice (a feature of virtually all Renaissance music, but taken to extremes in this repertory) and the strong encouragement to improvisatory addition suggests a relationship between text and performer akin to the participatory strategies so prominent in the Amadis novels. And in the same way that Amadis provided templates for female speech, the kind of piece associated with the Retz salon furnished models for women's song. Several of the airs discussed above - including Est-ce pas mort, $O$ combien est heureuse, and $A h$ dieu que c'est un estrange martyre - appeared in the text-only chansonniers published in large numbers in the last third of the century, where their tunes were designated as timbres for newly-written texts in feminine voices. $^{60}$ The economy of singing formulae permitted the creation of new utterance on the model as well as the reiterative performance of the model itself. This was an open-ended vocality in the same way as the notion of amadiser, gesturing toward a larger, do-it-yourself mode of musical expression in a way that a carefully crafted piece of counterpoint never could.

This flexibility of performance practice is echoed in the fluid musical form of strophic airs, which replicates the episodic construction of the Amadis novels. Performance of such pieces can easily involve transposition, repetition or elimination of strophes as well as the improvisatory addition of new strophes using the same music. That such procedures were regularly employed seems confirmed by the many variations found in printed manifestations of the repertory. Just as the additive construction of the Amadis novels helped to forestall closure and prolong the pleasure of reading, the varied repeat form of strophic song allowed performances of indeterminate length: add a strophe, repeat a strophe as you wish, the basic identity of the song is largely unaffected. In executing the pieces and assuming the guise of musical romantic heroines, female performers sang a version of desire similarly characterized by its resistance to definitive resolution, its quality of agonized yet pleasurable yearning toward an object unobtainable or interminably deferred. Such emotions - alluded to by the speaker of Ah Dieu que c'est un estrange martyre - are central to the libidinal economy constructed by these texts. Here we can understand "honor" as the concept that forces the postponement or denial of gratification, playing a crucial role in this configuration of feminine desire.

These observations prompt reflection on the ways that novels and song could serve not only as scripts for the vocal performance of a particular version of desire

${ }^{60}$ For example, Le plaisant jardin des belles chansons . . (Lyon: n.p. 1580) contains a song, Las quel malheur, to be sung to the tune of Est-ce pas mort; it is labelled "complainte d'une dame, sur le chant, Amour pense que je dors, Mais je me meurs" (p.98). For other instances, e.g. O combien est heureuse (an extremely popular timbre) see van Orden, "Female Complaintes." 
Musical Example 3.1 - Adrian Le Roy, Est-ce pas mort, from Second livre de chansons composé à quatre parties de plusieurs autheurs (Paris: Le Roy \& Ballard, 1564; R/1569 and 1577)
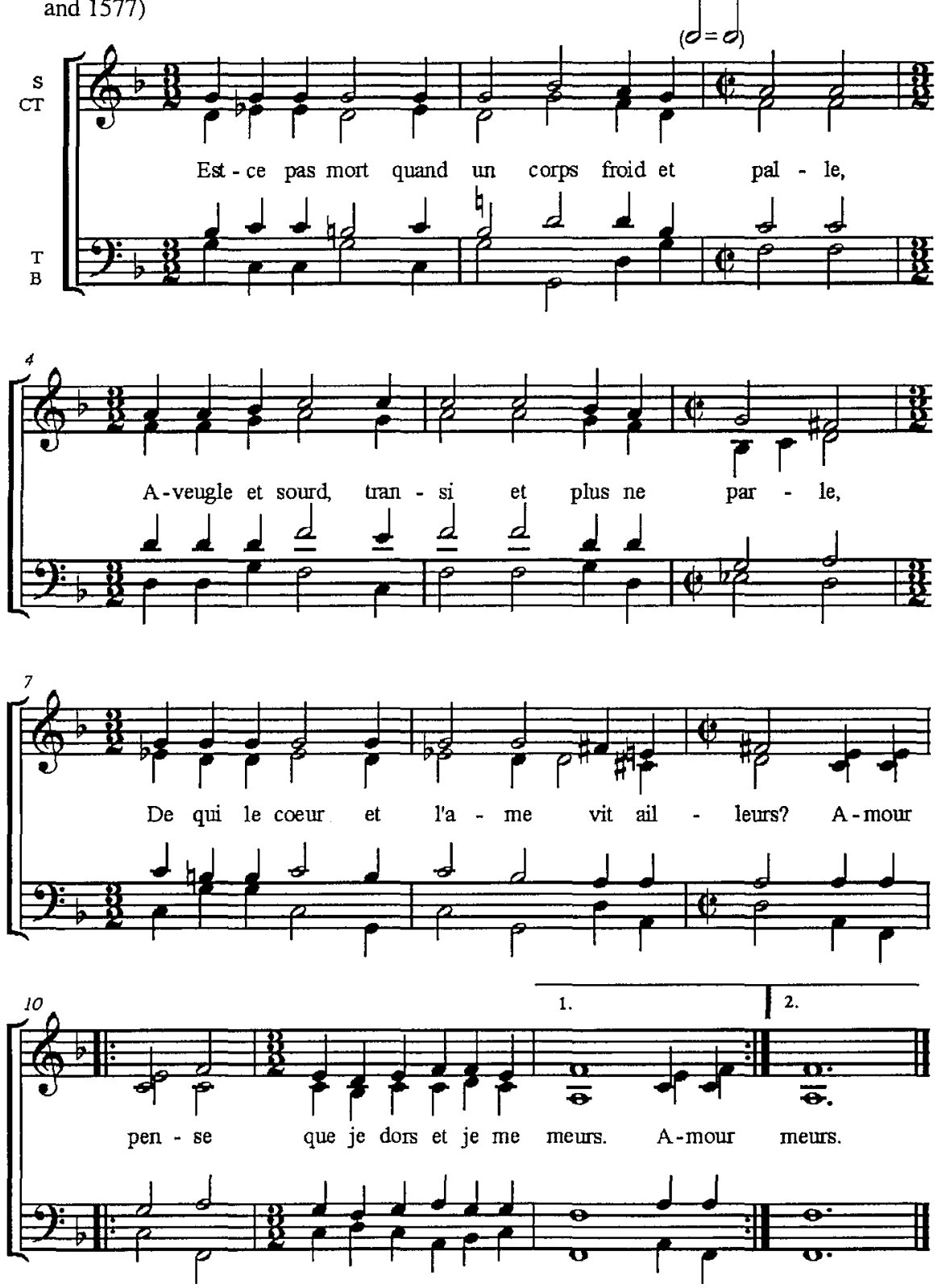

but as sexual objects in their own right. Jean Maugin's 1548 poem to female readers, pointing out that the new octavo editions would permit women to carry the books more easily, suggests that women in particular wished to keep copies of the 
book close to their bodies; that is, that their appetite for the narratives of the novel could translate into craving for the book as physical entity. A similar implication arises from Jacques Gohory's defense of the novel in the preface to his translation of Book 13. Gohory denounces women who in public condemn Amadis as dissolute, while in private they confess to their lovers that, as young girls, they delighted in reading the book by the nightlight's glow after their governesses ordered them to bed. ${ }^{61}$ Here Gohory presents a striking image of girls in bed with a book that teaches them desire, rehearsing with the novel the sexual experiences they will later share with male lovers. Performance of the narrative here becomes a simulacrum of heterosexual practice, interestingly short-circuited by the fetishistic and autoerotic character of the situation. An even more effective effacement of the male body occurs in a contemporary poem in which musicmaking with a lute becomes the substitute for heterosexual sex. The sonnet, which circulated at court in the early 1570 s (it is preserved in a manuscript emanating from the salon of Madeleine de l'Aubespine, wife of the secretary of state Nicolas de Neufville, sieur de Villeroy, and has been attributed to Madeleine herself or to Héliette de Vivonne), is an énigme or riddle poem. The answer to the riddle is "a lute," but the poem's wit lies in misleading the reader into thinking that the speaker is using a phallus as her instrument:

Pour le plus doulx esbat qui je puisse choisir Souvent apres disner craignant qu'il ne m'ennuye Je prends le manche en main je le touche et manye Tant qu'il soit en estat de me donner plaisir Sur mon lict je me jecte, et sans m'en desaisir Je l'estrains de mes bras sur mon sain je l'appuye Et remuant bien fort d'aise toute ravie Entre mille douceurs j'accompliz mon desir S'il advient par malheur quelquefois qu'il se lasche De la main je le dresse et derechef je tasche A joyr de plaisir d'un si doux maniment Ainsi mon bien aymŭ tant que le nerf luy tire Me contente et me plaist puis de moy doucement Lasse et non assouvye enfin je la retire.

D'un Luc.

[For the sweetest recreation I could choose, often, after dinner, fearing that he/it misses me, I take his/its neck in hand, I touch and manipulate it, until ithe is in a state to give me pleasure.

I throw myself on my bed, and without letting go of ithim, I clasp it/him in my arms, I lean it/him against my breast, and moving forcefully, with pleasure all delighted, among a thousand sweetnesses I accomplish my desire. If it happens, unhappily, that he/it slackens, 
I train it/him up with my hand, and once more I try

to enjoy the pleasure of such sweet handling.

Thus my well-beloved, as long as the string pulls him/it, contents and pleases me. Then from me, gently,

exhausted but not sated, I withdraw him/it. Of a Lute. $]^{62}$

Catherine de Clermont's own luxuriously copied poetry album contains two quatrains that ring changes on the idea of music-making with the lute as both metaphor and substitute for sex. In the first, love without sex is described as vain, like trying to play the lute with one hand:

Comme sans jouir de deux mains

Le luct ne produict nulle accordz

Ainsi tous les Amours sont vains

Qui ne joint ensemble deux Corps.

[As without playing with two hands, the lute creates no harmonies,

thus all love is in vain

that does not join together two bodies. $]^{63}$

In the second, the lute plays a role of the confidante whose harmonies "relieve the passions" of the suffering poet; its juxtaposition to the preceding quatrain suggests that the anguish may be physical:

Luct qui respond à mes affections

Qui particippe aux disdains de ma vie

Faitz je te prie que ta douce armonye

Puissent allegée [sic] toutes mes passions.

[Lute who responds to my emotions, who takes part in the distresses of my life, I pray you, make it so your sweet harmony will relieve all my passions. $]^{64}$

The poems appear in a section of the album where the hand of the principal scribe (a professional copyist) has given way to a series of different hands which seem to belong to Catherine, her friends and familiars, who added texts to the album after the main bulk of the copying was complete. Though the gender of the narrative

${ }^{62} F-P n$ fr. 1718 , fol. 57 r. On the provenance of the manuscript and attribution of the poem, see Lavaud, Philippe Desportes. The linguistically masculine gender of "un luth" in French allows for the ambiguity, as the pronoun "le" may be read as either "it" (referring to the lute) or "him" (a male lover). For a detailed discussion of the poem, see Carla Zecher, "The Gendering of the Lute in Sixteenth-Century French Poetry," Renaissance Quarterly 53 (2000): 787-789.

${ }^{63} \mathrm{~F}-\mathrm{Pn}$ fr. 25455 , fol. 145 r.

${ }^{64}$ Ibid. 
voice for these quatrains is not clear, the poems immediately preceding them adopt a feminine subject position, raising the possibility that the lute quatrains are the work of a woman, possibly Catherine herself.

Evidence such as this suggests that for female audiences, self pleasure was a major attraction of reading novels and making music. The opening of Book 1 of Amadis in fact sends strong cues in this direction, through the episode in which Dariolette masturbates at the thought of the pleasure her mistress will enjoy (as readers were meant to do when imagining the subsequent sex scene between Elisene and Perion?). It could be argued that such images are primarily voyeuristic: that their principal intention was to titillate male readers and listeners by appearing to offer them entry into an eroticised, private feminine physical and cultural space. However, as Helen Hackett has observed, the patriarchal fictions of romance must have offered some attraction to the female readers who embraced them with such enthusiasm; the appeal of sexual images to male readers need not have precluded their appropriation by women for their own affective purposes. ${ }^{65}$ Thus despite the role of their narratives in upholding patriarchal codes, books and songs may also have helped construct environments of desire in which female sexuality could effectively elude some forms of masculine control.

Here the expectation that romance would furnish a model for women's lives could cause particular anxiety, perhaps partly out of fear that female sexual desires, once so stimulated, would prove impossible to regulate. The idea that novels and songs encouraged women in unchaste behavior was fairly widespread in the late sixteenth century, as the actions of romantic heroines came to seem increasingly out of tune with the prevailing moral climate in the era of the religious wars. ${ }^{66}$ François de La Noue's 1581 essay "Que la lecture des livres d'Amadis n'est moins pernicieuse aux jeunes gens, que celle des livres de Machiavel aux vieux" [That the reading of Amadis books is no less pernicious for young people than the reading of Machiavelli's books for the old] furnishes the most detailed contemporary dissection of the novel's potential to lead women astray. In his treatment of the "poison de volupte" with which the novel corrupts its readers, he is particularly concerned with its ability to do so through sound. The French translators of the book have rendered the language so appealing that it reaches the passions through the ears: "Et l'ayant rendu fluide et affetté, il ne faut point demander si son murmure est doux aux oreilles, où apres avoir passé, il va chatouiller les plus tendres affections du coeur, lesquelles il esmeut, plus ou moins, selon que les personnes sont preparees." ${ }^{, 67}$ He goes on to condemn the effect on young women in particular before citing the incipit of a popular song, "Tant vous

${ }^{65}$ Hackett, Women and Romance Fiction, 11-12 and 68-75.

${ }^{66}$ For a detailed examination of the growing divergence, see Rothstein, Reading in the Renaissance, 125-144.

67 "And having rendered the language flowing and ornate, we need not ask if its murmuring is sweet to the ears, after passing through which it goes to tickle the most tender feelings of the heart, which it moves, more or less, depending on the degree to which the individual is prepared." La Noue, Discours, 169. 
allez tost Guillemette," to illustrate how rashly young women behave when under the influence of Amadis. Though the song is a rather rough-and-ready chanson rustique, it circulated at court and was published by the royal printer in $1565 ;{ }^{68}$ its distribution overlaps with that of the voix de ville and airs de cour I have been discussing. La Noue frequently cites psalms in support of his arguments, but this is the only instance in his Discours politiques et militaires in which he refers to a specific piece of secular music. Clearly, for La Noue, novels and songs inhabited the same world - a perilous world for women. His fears were perhaps not unfounded: Catherine de Clermont had a long liaison with the courtier Charles de Balsac d'Entragues, and was rumored to have had his child; ${ }^{69}$ Henriette de Clèves and Marguerite de Valois lived sentimental lives of such notoriety and romantic dimensions that they later furnished the plot of one of the most famous romances of the nineteenth century, Alexandre Dumas's La Reine Margot.

While sixteenth-century actors were principally concerned with whether or how romance encouraged illicit sexual activity, feminist historians today ask different questions. Were songs and romance opiate or opportunity? Can they be considered a repressive or liberatory force in noblewomen's lives? Perhaps the best answer is both. Romance and related lyric types furnished valuable affective latitude for some aristocratic women by offering imaginative contexts for the articulation of feminine desire. As inscriptions of and scripts for female vocality, romance and song offered a range of possibilities for the active participation of female readers and singers in emotional expression through performance. These observations have a particular piquancy when applied to songs and speeches about suffering desire in silence and indulging it in secret. Female sexuality rhetorically figured as silence - already problematic in textual terms - becomes an even more profound paradox when real women give voice to that silence in the world. The articulation of silence as sound invested women with the power to shape and manifest their desires through identification with the longing subject of novel or song. At the same time, the constant evocation of honor as foil to desire reassured their audiences and themselves that the social structures that controlled their actions were still firmly in place. While songs and novels allowed women to give audible form to emotions that would, in other contexts, be impossible to reveal, they also helped to ensure that female sexual activity remained highly controlled and that trespasses against honor could legitimately exact heavy tolls. Treading a precarious path through interdictions simultaneously flouted and reinforced, romances and songs provided opportunities for women to voice their passions, yet supported the discourse that upheld their silence as ideal.

68 The song appears as "Tant vous allés doux Guillemette," in a polyphonic arrangement attributed to Abran, in Quinsieme livre de chansons á quatre cinq et six parties (Paris: Le Roy \& Ballard, 1565), fols. 11r-12r.

69 Jullien de Pommerol, Albert de Gondi, 199-201. 


\section{Appendix 1}

$I$ Est-ce pas mort quand un corps froid et palle, Aveugle et sourd, transi et plus ne parle De qui le coeur et l'ame vit ailleurs: Amour pense que je dors et je me meurs.

2 Est-ce pas mort quand un autre a sa vie Qui fuit son bien et force son envye Qui veut et n'ose appaiser ses douleurs. Amour.

3 Est-ce dormir quand sans cesse je veille, Et que l'amour en dormant me reveille, Pour me transir en regretz et en pleurs. Amour.

4 Est-ce dormir quand un desir me ronge Toute la nuit et que tousjours je songe Que je te baise, helas songes menteurs. Amour.

5 Certes c'est mort ou plus cruel martire Puis que les mortz ne souffrent rien de pire Que de finir par la mort leurs malheurs.

Amour.

6 Mais moy je meurs et si vis tout ensemble Et sans mourir tousjours morte je tremble Pour ne jouir des biens qui me sont seurs.

Amour.

7 O vie, ô mort, o mon peu d'hardiesse Quand folle n'ose employer ma jeunesse Et que j'yveme mon printemps, et mes fleurs. Amour.

8 Donques pour vivre, il faut que je jouisse Mais cest honneur ne veult que j'acomplisse Heur plus heureux du plus grand de mes heurs. Amour.

9 Mortel honneur helas la patience

De me veoir morte en fuiant jouissance

Me fait souffrir mil' autres deshonneurs. Amour.

10 Las! qui me veoit plus mourante que vive Juge fort bien ma volunté craintive Et que la peur refroidit mes challeurs. Amour.

$11 \mathrm{O}$ bras trompez, qui durant les nuitz sombres Allez au lit n'accollans que les umbres Voz doitz me soyent fidelles serviteurs. Amour.

12 Las que celuy qui fait que je palice Me feroit bien plus que vous de service
[Is it not death, when a cold and pale body, blind and deaf, rigid, no longer speaks, of whom the heart and soul live elsewhere?

Love thinks I sleep, but I die.

Is it not death when another has one's life, to flee one's own good and force one's will, to wish but not dare to appease one's pains?

Love...

Is it sleep, when without cease I wake and when love in sleeping awakens me to transfix me in regrets and tears?

Love...

Is it sleep, when a desire gnaws me all night, and $I$ always dream that I kiss you? alas, lying dreams!

Love...

Surely this is death, or an even crueller torture, for even the dead suffer nothing worse than to finish their misfortunes through death.

Love...

But I, I live and yet die at once and without dying, still dead I tremble from not enjoying the joys sure to me.

Love...

O life, o death, o my own lack of courage, since foolishly I dare not use my youth, and cast winter on my springtime and my flowers.

Love ...

Thus to live, I must take pleasure but this honor does not wish me to achieve that happiness which is the greatest of my joys.

Love...

Deadly honor, alas, the patience to see myself dead in fleeing enjoyment makes me suffer a thousand other dishonors. Love...

Alas! whoever sees me more dying than alive, can well judge my frightened will, and that fear cools my heat.

Love...

O cheated arms, who during the dark nights go to bed embracing only shadows, let your fingers be faithful servants to me.

Love...

Alas, he who makes me grow pale would do me far greater service than you, 
Mais las je n'ose approcher ses grandeurs. Amour.

I3 Il m'est advis si tost que j'en approche

Las que desja un chacun me reproche

Que j'ay reçeu le bien de ses doulceurs. Amour.

14 Mais par despit la peur et l'amour forte

M'endormiront bien tost de telle sorte

Qu'un autre mort finira mes douleurs Amour.

15 Dont finiront cent mille mortz pour une

En triumphant par mort de ma fortune

Et du malheur de mes mortelles pleurs. Amour.
But alas, I dare not approach his greatness.

Love...

I think each time that I approach him, alas, that already everyone reproaches me thinking that I have received the joy of his caresses.

Love...

But out of spite, fear and powerful love will soon send me to sleep in such a way, that another death will finish my pain.

Love...

So a hundred thousand deaths will finish for one and I will triumph through death over my fortune and the unhappiness of my mortal tears.

Love...]

Appendix 2: Le trezieme livre d'Amadis de Gaule, trans. Jacques Gohory (Paris: Breyer, 1571), fols. 22r-22v: . . . la gente Marfire demeura en si grand desplaisir . . . qu'elle desiroit mourir de dueil tellement que quasi plus ne mangeoit, plus ne reposoit jour ne nuict en aucune maniere: dont sa beauté alloit fort decheant et amoindrissant. Elle en cheut au lit malade, où de jour à autre sa maladie augmentoit, jusques à ce que se voiant pres du riquet de la mort, print Cardonie sa damoiselle par la main et avecques grands sanglots luy commença à dire: Cardonie m'amie, vous sçavez bien que jamais je ne vous ay rien celé de ce que j'ay eu sus mon cueur, et moins ores le ferai-je. Pourtant vous devez sçavoir, m'amie, que la raison de mon honneur, ne la grandeur de ma beauté, ne la rigueur dont j'ay usé à l'endroit du vaillant Prince Filisel, n'ont peu avoir tant de pouvoir, que l'excellence de sa beauté n'ait tout mis soubs le pied, et moy reduitte au piteux estant que me voiez, Auquel je ne sens en moy force ne vertu de pouvoir plus gueres prolonger ma vie...

[. . . the lovely Marfire remained in such discontent . . . that she wished to die of grief so that she hardly ate, and night or day did not rest at all: from which her beauty was greatly fallen and diminished. She fell sick to her bed, where from day to day her illness increased, until seeing herself at death's door, she took her maidservant Cardonie by the hand and with great sobs began to say to her: "Cardonie my friend, you know well that I have never concealed from you what I hold in my heart, and even less will I do so now. Yet you must know, my friend, that neither the cause of my honor, nor the greatness of my beauty, nor the rigor that I have exercised against the valiant prince Filisel, have had enough power to prevent the excellence of his beauty from crushing all underfoot, and reducing me to the pitiful state in which you see me, in which I no longer feel in myself the strength or virtue to be able to prolong my life much longer ...']

Appendix 3: Le premier livre d'Amadis de Gaule, trans. Nicolas de Herberay des Essarts, ed. Yves Giraud and Hugues Vaganay (Paris: Société des Textes Français Modernes, 1986), 1: 10-11: Le temps estoit lors gracieux et serein, la lune belle et 
luysante, qui donnoit clarté aux deux damoyselles. Mais certes l'une avoit plus d'occasion d'estre contente que l'aultre, qui eust tresvoluntiers pris ce bien, ou ung semblable pour elle mesme, si elle en eust eu moyen, et tant en donnoit de cognoissance, que Elisene voyoit bien, qu'il n'y avoit faulte que de executeur pour y satisfaire, car ceste Dariolette, sentant en son esperit l'ayse prochain, que debvoit recevoit celle, qu'elle conduisoit, ne se povoit tenir de luy manier, puis les tetins, puis les cuysses et quelque chose d'advaintaige, et de trop vehemente ardeur souspiroit souvent, tout ainsi que si elle eust deu participer à ce bien futur de la princesse Elisene, à laquelle elle disoit: Helas madame, que heureulx est le prince, par lequel vous recevrez ceste nuict tant de plaisir.

[Then the weather was pleasant and serene, the moon beautiful and gleaming, which provided light for the two maidens. But one certainly had greater cause to be happy than the other, who would very willingly have taken that good, or a similar one, for herself if she had had the means, and she showed this so much, that Elisene saw clearly that only an executor was needed to satisfy her, for that Dariolette, feeling in herself the pleasure that the woman she was accompanying was about to receive, could not refrain from touching herself on the breasts, thighs and something else as well, and from her over-fervent ardor, sighed frequently, just as if she had been participating in the future delight of princess Elisene, to whom she said: "Alas, my lady, happy is the prince from whom tonight you will receive such pleasure.']

Appendix 4: Le trezieme livre d'Amadis de Gaule, fols. 96v-97v:

Specialement Sidere vivoit en grieve desplaisance de ne luy [Rogel de Grece] avoir plustost ottroyé son amoureuse requeste, se plaignant en ses regrets de l'honneur, comme de bourreau, comme de meurdrier des miserables amantes, principalement de celles de son estat royal qui s'y estimoient plus obligées pour servir d'exemple aux autres. Ha (disoit elle à par soy) que ne luy avois je tranché le mot à notre arrivée de trouver le lieu de commodité, dont tant il m'importunait que avec l'obligation de ma delivrance, je pouvois estre trop excusée de le consentir: Las (discouroit elle) ... je devois plustost sans attendre tant de dangers, tant de regards et conterolles ... le recompenser de ses bienfaits en la commodité du long voyage que nous faisions ensemble. Puis recommencoit, ha faux honneur, garde de la chasteté des Dames, il ne fut oncques de plus cruel tiran que toy qui les gesnes, tourmentes et fais mourir à petit feu, $\mathrm{O}$ que je luy en escrirois volontiers ce que ne n'ay osé luy dire de bouche: la main estant plus hardie qui ne rougit point que la langue si prochaine de la face honteuse, mais la lettre escritte demeure, en danger d'estre veue et descouverte, portant suffisante preuve en soy de la condemnation de l'honnesteté.

[Above all Sidere lived in grievous unhappiness that she had not rather acceded to the amorous appeal of Rogel de Grece, in her laments complaining of honor, as an executioner, a murderer of miserable [female] lovers, especially those of her royal standing who thought themselves more obliged by it to serve as an example for 
others. "Ah," she said to herself, "why did I not interrupt him as soon as we arrived here to find a convenient meeting-place, for which he begged me so, that with the debt I owe him for having rescued me, I could easily have been excused for consenting. Alas," she continued, "instead of awaiting such dangers, so many gazes and checks ... I should have rewarded him under the more opportune circumstances of the long voyage we made together." Then she started again, "Ah, treacherous honor, guardian of women's chastity, there was never a crueller tyrant than you, who restrain and torment them, and slowly torture them to death! Oh, I would willingly write to him all I have not dared tell him aloud, for the hand does not blush and is braver than the tongue, which is so close to the abashed face, but the written letter remains, in danger of being seen and discovered, in itself providing sufficient proof for the loss of reputation."]

\section{Table 1}

Music prints associated with Catherine de Clermont, Adrian Le Roy and the early history of the air de cour

1) Premier livre de chansons, en quatre volumes, nouvellement composées en musique à quatre parties, par M. Pierre Certon (Paris: Le Roy \& Ballard, 1552). Strophic songs in polyphonic arrangement.

2) Second livre de guiterre, contenant plusieurs chansons en forme de voix de ville: nouvellement remises en tabulature, par Adrian Le Roy (Paris: Le Roy \& Ballard, 1555 [1556 n.s.]). 2nd ed. of a lost print published between the appearance of the Premier livre de tabulature de guiterre on 12 September 1551 and the Tiers livre de tabulature de guiterre of 1552; may have been printed before (1). Contains texted monophonic melodies in white mensural notation with facing guitar arrangements in tablature of strophic songs, mainly from (1).

3) Second livre de chansons, nouvellement mises en musique à quatre parties, par bons et sçovans musiciens (Paris: Le Roy \& Ballard, 1554). Predominantly strophic songs in polyphonic arrangement, attributed to Le Roy, Certon, Maillard, Arcadelt, Mithou and Entraigues.

4) Premier livre de chansons composé en musique à quatre parties par $M$. Pierre Certon (Paris: Le Roy \& Ballard, 1564). Revised ed. of (1) replacing four songs with four others by Certon from (3).

5) Second livre de chansons composé à quatre parties de plusieurs autheurs (Paris: Le Roy \& Ballard, 1564; R/ 1569 and 1577). Heavily revised ed. of (3), contains 3 strophic songs by Le Roy amid songs by Nicolas. 
[6) Breve et facile instruction pour apprendre la tablature . . (Paris: Le Roy \& Ballard, 1567; no copy extant).]

7) $A$ briefe and easye instru[c]tion to learn the tableture . . englished (London: Rowbothome, 1568). English translation of (6)

8) Chansons de P. de Ronsard, Ph. Desportes, et autres, mises en musique par $N$. de la Grotte (Paris: Le Roy \& Ballard, 1569; R/ 1570, 1572, 1573, 1575, and 1580). Strophic songs in polyphonic arrangement.

9) Musique de Guillaume Costeley, organiste ordinaire et vallet de chambre, du treschretien et tresinvincible roy de France (Paris: Le Roy \& Ballard, 1570). Contains dedicatory sonnets by Costeley to Albert de Gondi and Catherine de Clermont; Latin poem by Jacques Gohory. Includes a section of strophic songs labelled "meslange de chansons en façon d'airs."

[10) Instruction de partir toute musique des huit divers tons en tablature de luth. . (Paris: Le Roy \& Ballard, 1570; no copy extant). Dedicated to Catherine de Clermont, preface by Jacques Gohory. Possibly included a re-edition of (6).]

11) Livre d'airs de cour miz sur le luth, par Adrian Le Roy (Paris: Le Roy \& Ballard, 1571). Dedicated to Catherine de Clermont. Contains texted monophonic melodies in white mensural notation with facing lute arrangements in tablature of strophic songs, mainly from (8); shares 1 piece each with (5) and (12).

12) Premier livre de chansons en forme de vau de ville composé à quatre parties, par Adrian Le Roy (Paris: Le Roy \& Ballard, 1573). New polyphonic arrangements of songs from (1), (2), (3), (4) and (11) plus three new pieces.

13) A briefe and plaine Instruction to set all musicke of divers Tunes in Tableture for the Lute . . . with a brief Instruction how to play on the Lute by Tablature . . also a third Booke containing divers new excellent tunes. All first written in french by Adrian Le Roy (London: Rowbothome, 1574). English translation of material from (6), (10) and (11), including dedication to Catherine de Clermont and preface by Jacques Gohory from (10). 